Cahiers du MONDE RUSSE

\section{Cahiers du monde russe}

Russie - Empire russe - Union soviétique et États indépendants

40/1-2 | 1999

Archives et nouvelles sources de l'histoire soviétique, une réévaluation

\title{
Interpreting the new archival signals
}

Nationalities policy and the nature of the Soviet bureaucracy

\section{Terry MARTIN}

\section{CpenEdition}

\section{Journals}

Electronic version

URL: http://journals.openedition.org/monderusse/6

DOI: $10.4000 /$ monderusse. 6

ISSN: $1777-5388$

\section{Publisher}

Éditions de l'EHESS

\section{Printed version}

Date of publication: 1 January 1999

Number of pages: 113-124

ISBN: 2-7132-1314-2

ISSN: $1252-6576$

\section{Electronic reference}

Terry MARTIN, «Interpreting the new archival signals », Cahiers du monde russe [Online], 40/1-2 | 1999, Online since 15 January 2007, Connection on 01 May 2019. URL : http://journals.openedition.org/ monderusse/6 ; DOI : 10.4000/monderusse.6 


\title{
INTERPRETING THE NEW ARCHIVAL SIGNALS
}

\author{
Nationalities policy and the nature \\ of the Soviet bureaucracy
}

THE SUDDEN AVAILABILITY OF NEW SOURCES is always a great blessing for the historian, but it is naturally not an uncomplicated blessing, since new sources can initially deceive as well as enlighten. My article will focus on this potential for deception. My observations are based on research undertaken from 1993 to 1995 for a dissertation on Soviet nationalities policy. ${ }^{1}$ I will first present a brief overview of the new archival sources now available for the study of Soviet nationalities policy in the inter-war period. Then I will sketch out a theory of how the Soviet bureaucracy functioned at that time (a theory based entirely on my own confrontation with the new archival sources), and suggest how a failure to appreciate the unusual nature of Soviet bureaucratic practice can easily lead researchers into serious interpretive errors.

The bulk of my research took place in five archives: the former All-Union Party and State Archives (RTsKhIDNI, GARF), the former RSFSR State Achive (GARF-TsGA), and the former Ukrainian Party and State Archives (TsDAHOU, TsDAVOU). I also worked less extensively in the Central Economic (RGAE) and Military Archives (RGVA). I consciously endeavored to consult records from a broad base of different bureaucratic institutions. The nature of the Soviet bureaucracy necessitates such an approach.

1. Terry Martin, An Affirmative Action Empire: Ethnicity and the Soviet State, 1923-1938 (Ph.D. diss., University of Chicago, 1996). Forthcoming from Cornell University Press, 1999. 
The Stalinist bureaucracy can be divided into soft-line and hard-line institutions. ${ }^{2}$ Soft-line institutions dealt openly with the Soviet public and their job was to present the regime's policies in as attractive a light as possible. Typical soft-line tasks were receiving petitions and petitioners, correcting excesses (peregiby), restoring rights, bestowing awards, providing a forum for mass participation in elections and soviets. Hard-line institutions, on the other hand, specialized in maintaining Bolshevik vigilance and insuring the implementation and preservation of core Bolshevik policies and values. Typical hard-line activities would be unmasking enemies, promoting vigilance, receiving denunciations, arresting and deporting enemies. Above all, terror. Therefore, any study based on the archives of only soft-line or hardline institutions will inevitably lead to gross distortions of reality. ${ }^{3}$

This problem is particularly acute with nationalities policy, since the Bolshevik leadership assigned its implementation to the most unambiguously soft-line bureaucracy: TsIK (Tsentral'nyi ispolnitel'nyi komitet - Central Executive Committee). TsIK was the name given to the Soviet parliament (renamed the Supreme Soviet in 1938). It convened quite rarely and had little importance in the inter-war period. A permanent Presidium, of greater significance, was appointed to carry on business entrusted to the parliament between sessions. TsIK's Presidium was in charge of the process known as "soviet construction" (sovetskoe stroitel'stvo), which consisted of the creation and supervision of a network of government soviets across the entire Soviet Union down to the village level. Outside the industrial workplace, these soviets served as the regime's main source of direct contact with the Soviet populace. The head of TsIK (and its Russian equivalent, VTsIK) was Mikhail Kalinin. Cast in the paternal role of "all-Union village elder" (vsesoiuznyi starosta) who received the people's (especially the peasants') petitions and corrected abuses, Kalinin was the embodiment of the Soviet soft-line. ${ }^{4}$

2. For an account of how this bureaucratic division functioned in the sphere of religious policy, see Terry Martin, "Cults Commission (1929-1938)," The modern encyclopedia of religions in Russia and the Soviet Union (Gulf Breeze, FL, 1995), 6 : 142-148. For a recent study of the Cults Commission that disputes my interpretation, see Arto Luukkanen, The religious policy of the Stalinist state. A case study: The central standing commission on religious questions, 19291938 (Helsinki, 1997).

3. The closest approximation I have encountered to my theory of Soviet bureaucratic practice is Vladimir Shlapentokh's discussion of "public" and "closed party" ideology in the Brezhnev era. Shlapentokh does not discuss the function of different bureaucracies and wrote prior to the opening of the Soviet archives. Still, as I do, Shlapentokh points to the coexistence of two rival communication flows. He properly does not dismiss the "public" ideology as false or mere propaganda, but instead insists that "the open public and closed party ideologies [are] in intensive interaction" (xiii). He also notes the source problem this creates, that the confusion of these two levels of discourse was "an endemic weakness of many Sovietological studies, which, in the quest for factual information and references, quite often [took] at face value the written materials and oral statements produced by Soviet leaders and their people" (xiii). Finally, he also emphasizes a multi-source approach in order to deal with the built-in biases of both public and closed sources. Shlapentokh's theory is presented in the introduction to Vladimir Shlapentokh, Soviet public opinion and ideology. Mythology and pragmatism in interaction (New York, 1986).

4. Kalinin's counterpart in Ukraine, Grigorii Petrovskii (head of VUTsIK, the Ukrainian TsIK), adopted an identical persona, even sporting a similar peasant-friendly beard. An even more paradigmatic exemplar of the soft-line was Petr Smidovich, a member of VTsIK's Presidium 
A sub-division of sovetskoe stroitel'stvo was natsional'noe stroitel'stvo, the creation of a network of national soviets, which in effect meant national territories, across the entire Soviet Union. In order to administer this effort, TsIK included a Soviet of Nationalities (Sovet natsional'nostei), which had its own permanent Presidium. The records of this institution are reasonably well-preserved and provide an especially valuable source for the otherwise poorly represented period from 1935 to 1937.5 VTsIK and its Nationalities Department (Otdel natsional'nostei) carried out the same functions within the RSFSR. The records of VTsIK's Nationalities Department are particularly useful for the study of extraterritorial national minorities. These records are well-preserved only for the years from 1925 to 1931.6 Finally, the Commissariat of Education (Narkompros RSFSR), also a paradigmatic soft-line institution, supervised native-language education through its Nationalities Committee (Komnats) until the abolition of Komnats in 1934. The papers of Komnats contain the best records on the massive all-Union Affirmative Action programs in higher education during the cultural revolution. ${ }^{7}$ These were the three major central soft-line institutions with responsibility for nationalities policy. ${ }^{8}$

With the exception of the Soviet secret police (the OGPU-NKVD), the hard-line institutions dealing with nationalities policy were all located within the Communist Party's Central Committee (TsK). ${ }^{9}$ TsK contained a Nationalities Subdepartment

from 1918 to 1935, who specialized in the re-opening of "illegally" closed churches, the settlement of Jews on agricultural land, the protection of the small peoples of the north, and the "greening" of Soviet factory grounds and cities. For Smidovich's autobiography, see Deiateli SSSR i revoliutsionnogo dvizheniia Rossii (Moscow, 1989): 674-675.

5. The papers of the Soviet of Nationalities do not form a separate archival fond, but are instead interspersed with the papers of TsIK in GARF, f. 3316. The quantity of documentation waxes and wanes in parallel with the organization's spurts of activity and quiescence. Documentation is particularly good for the periods 1927-1929 and 1935-1937, and abysmal for the period 1931-1934.

6. Included with the papers of VTsIK in GARF, f. 1235, op. 118-132. Records from 1932 to 1938 are quite poorly preserved.

7. Komnats has a separate fond in GARF (TsGA), f. 296. In the 1920s, Komnats was known as Sovnatsmen (Sovet natsional'nykh menshinstv).

8 . These bureaucracies sponsored a wide range of journals, which serve as indispensable sources for the study of Soviet nationalities policy. Among the journals published by TsIK were Sovetskoe stroitel'stvo, Revoliutsiia i natsional'nosti, Kul'tura i pis'mennost' vostoka, Natsional'naia kniga and Kommunisticheskii vostok. Among the journals published by VTsIK were Vlast' sovetov and Sovetskii sever. Non-Russian education policy was covered by Prosveshchenie natsional'nostei. The fact that all specialty journals devoted to nationalities policy were published by soft-line institutions makes the danger of adopting a soft-line bias particularly problematic for students of nationalities policy who do not consult archival materials.

9. Again, this division is typical. TsIK represented the bureaucratic soft line, TsK and the OGPU the bureaucratic hard line. In religious policy, the soft line was represented by the Permanent Commission on the Affairs of Religious Cults (pri VTsIK until 1934 and pri TsIK from 1934 to 1938), the hard line by TsK's Commission on the Execution of the Decree on the Separation of Church and State (informally and more accurately known as the Antireligion Commission) and of course by the OGPU, which had a separate department assigned to monitor and undermine religious organizations. 
(Natsional'nyi podotdel), but the influence of this institution was trivial, and if it in fact produced a significant amount of paperwork before its abolition in 1930, only a small amount has been preserved. ${ }^{10}$ Vastly more important was TsK's influential Orgraspred Department (Organizatsionno-raspredelitel'nyi otdel), which was in charge of supervising nationalities policy implementation in the Soviet Union's union republics, autonomous republics and autonomous oblasti. ${ }^{11}$ The Orgraspred Department had instructors who specialized in the nationalities question and engaged in periodic inspections. Their reports are exceptionally valuable.

The Orgraspred Department reported to TsK's Orgbiuro (Organizatsionnoe biuro), which periodically listened to reports from the First Party Secretaries of various national regions. ${ }^{12}$ These Orgbiuro materials are of enormous interest, since they contain dozens of stenograms relating to various nationalities policy issues. Most of these stenograms contain comments (albeit often brief ones) from the Party Secretary in charge of the Orgbiuro. ${ }^{13}$ Unfortunately, Orgbiuro materials relating to nationalities policy gradually decline after 1929 and largely disappear after 1933.14 The Politbiuro frequently considered questions relating to nationalities policy, but only the bare protocols of its meetings are currently available..$^{15}$ In addition to these bureaucratic institutions, TsK's Information Department contains a wealth of data on social processes in the national regions. ${ }^{16}$ Of greatest interest are the regular reports (svodki) from the OGPU on the mood of the populace. Finally, although the All-Union Central Control Commission (TsKK) generally ignored nationalities policy, it did engage in a massive inspection of nationalities policy in 1929 which resulted in thousands of pages of extremely interesting materials. ${ }^{17}$

This division of the Soviet bureaucracy into soft-line and hard-line institutions represents, in my opinion, the single greatest potential for the new archival sources to distort the historical record. In nationalities policy, the job of soft-line institutions was almost exclusively positive: to service and increase the number of

10. These records are interspersed throughout RTsKhIDNI, f. 17, op. 60.

11. RTsKhIDNI, f. 17, op. 67-69, 74 .

12. RTsKhIDNI, f. 17, op. 112-114.

13. From 1924 through 1931, these were Molotov, Kosior, Kaganovich and Postyshev. Molotov typically said very little. Kosior and Kaganovich spoke more freely. Stalin virtually never attended the Orgbiuro after 1923. I found only three stenograms relating to nationalities policy where Stalin was present and spoke. All three related to the removal of a First Party Secretary (Tatarstan and Transcaucasus) or the assignment of a Second Party Secretary to "support" a failing First Party Secretary (Bashkiria). In the Transcaucasus stenogram, to my great grief, Stalin's speech had been removed from the stenogram, although his frequent repartees were left in the record.

14. With the exception of some exceedingly important materials from late 1937 and early 1938.

15. RTsKhIDNI, f. 17, op. 3, 162, 163. As of May 1999, the materials to the Politbiuro sessions remain closed to researchers (except those with special influence) in the Presidential Archive.

16. RTsKhIDNI, f. 17, op. 17-32, 42, 87. Similar informational materials are contained in the records of the sekretnyi otdel in RTsKhIDNI, f. 17, op. 33, 84-86.

17. These are contained in GARF, f. 374, op. 27. 
national soviets, schools, newspapers, theaters, written languages, museums, folk music ensembles, and so forth. The job of hard-line institutions was much more negative: to engage in surveillance over the implementation of nationalities policy and, when necessary, to take measures to prevent the intended development of national self-consciousness from evolving into an undesired growth of separatist nationalism. This division of bureaucratic responsibility was often so stark that the records of soft-line institutions do not even mention actions being simultaneously undertaken by hard-line institutions. ${ }^{18}$ I will sketch out two instances where an exclusive focus on either soft-line or hard-line institutions would seriously distort one's understanding of Soviet policy.

My first example is Ukrainization, the policy of establishing Ukrainian as the exclusive language of government in the Ukrainian SSR. ${ }^{19}$ Through April 1925, Ukrainization exemplified the characteristic soft-line/hard-line bureaucratic division of labor. Soft-line institutions - such as the Ukrainian TsIK, Sovnarkom and Narkompros - were assigned the task of implementing Ukrainization. The Ukrainian TsK and GPU, while supporting the policy in principle, focused their energy on preventing the growth of nationalism, which entailed a highly skeptical attitude towards Ukrainization. Neutral institutions - the commissariats and trusts who were not responsible for supervising nationalities policy, but were required to Ukrainize their institution's paperwork - interpreted this difference in bureaucratic enthusiasm as follows: Ukrainization was a low priority policy and therefore its implementation could be stalled. Such institutions were flooded with an unfulfillable number of central directives. In deciding which items to give highest priority, they had to interpret central signals and decide whether a given

18. This was very much the case in religious policy. TsIK's Cults Commission confined itself almost exclusively to two tasks. The bulk of its attention went to hearing petitions to re-open closed churches (about one-third of such petitions were successful). A secondary issue was the restoration of rights for religious officials. The Commission's records are extremely formulaic. Local officials alone are blamed for peregiby and are censured when a decision is reversed. There is absolutely no mention, even in the private and secret deliberations of the Commission, that the assault on religion had been organized by TsK and the OGPU, and that local officials acted in response to their unambiguous signals. This is the same process by which collectivization was carried out: menacing but vague hard-line signals from above combined with targeted OGPU terror by quota, which led to aggressive action by local officials terrified of being accused of a rightist deviation (of course, there were also plenty of active supporters among local officials, who only needed to be unleashed). This was followed by limited central sanction of local peregiby, though not of OGPU quota fulfillment. The intentional and functional nature of this strategy is nicely analyzed in N. A. Ivnitskii, Kollektivizatsiia $i$ raskulachivanie (Moscow, 1996). The interesting thing about religious policy is that the cycle of central hard-line signals leading to aggressive local actions and then selected soft-line censure of peregiby was not confined to the period 1928-1931, but continued throughout the 1930s. The Cults Commission did not ignore hard-line actions due to a lack of information. Smidovich, head of the Cults Commission, was a member of TsK's Anti-Religion Commission and Tuchkov, the OGPU's religion specialist, sat on Smidovich's Commission. The hard-line policy simply lay entirely outside the competence and job description of the Cults Commission.

19. Here I summarize arguments developed more fully in T. Martin, An Affirmative Action Empire, op. cit.: 117-168, 400-428. Ukrainization also involved the promotion of ethnic Ukrainians into positions of leadership. I do not deal with that aspect of the policy here. 
policy item had hard-line support, and therefore must be implemented, or merely soft-line support, and therefore could be deferred.

These signals changed dramatically with the arrival of Lazar Kaganovich as the new Ukrainian First Party Secretary in April 1925. Kaganovich immediately formed a special Politbiuro Commission to supervise the implementation of Ukrainization. The Politbiuro Commission met regularly and Kaganovich chaired the meetings himself. Kaganovich emphasized the necessity of a "hard line" (tverdaia liniia) on Ukrainization. ${ }^{20}$ These changed signals immediately altered the calculations of the neutral institutions. The vast majority of them shifted their paperwork to Ukrainian by Kaganovich's deadline of January 1st, 1926. The only hold-outs were the all-Union economic commissariats and trusts, who had central political patrons and adopted the stalling strategy of claiming that Ukrainian government decrees did not apply to them. In effect, they were waiting to see whether the center would force them to Ukrainize. The ultimate signal of the center's hard-core commitment to any policy's implementation was the use of terror. Thus far, terror had never been used by the center in order to force the implementation of nationalities policy, though it had been used to combat the growth of separatist nationalism.

The launching of Stalin's "revolution from above" in 1928 immediately scrambled the signals being sent on nationalities policy. A large segment of Party opinion assumed that since the soft-line policy of smychka (alliance) with the peasantry had been decisively abandoned, the soft-line compromise with national consciousness would likewise be forsaken. ${ }^{21}$ In a series of private and public comments, Stalin rejected this interpretation. Instead, he insisted that the new socialist offensive would instead lead to an acceleration of Soviet nation-building (and therefore Ukrainization) and a rapid flourishing of the Soviet Union's national cultures. This became the official policy line and was duly repeated by Ukraine's major political leaders. However, at exactly the same time, the Ukrainian GPU and Politbiuro, with the center's sanction, organized an extensively publicized show trial of the so-called SVU (Spilka Vyzvolennia Ukrainy). This "Ukrainian Shakhty" involved the trial of prominent ethnic Ukrainian intellectuals, who were accused of plotting with the Polish and German government to separate Ukraine from the Soviet Union. ${ }^{22}$ The all-Union economic Commissariats and Trusts, therefore, received two conflicting signals: public policy statements that Ukrainization should be accelerated and terror directed against Ukrainian "nationalists." Terror trumped discourse. These institutions ceased Ukrainization

20. RTsKhIDNI, f. 17, op. 85, d. 4 (1926), 11. 3, 7.

21. A significant segment of Party opinion had always interpreted the 1923 nationalities policy as a NEP-era concession to the nationalities which would be reversed when NEP came to an end. Stalin consistently rejected this position and his actions in 1928-1930 and after indicate that he never viewed nationalities policy in those terms.

22. On the trial, see Volodymyr Prystaiko, Iurii Shapoval, Sprava "Spilky Vyzvolennia Ukrainy." Nevidomi dokumenty i fakty (Kiev, 1995). 
and by the end of 1930, the goal of comprehensive linguistic Ukrainization had been effectively abandoned. ${ }^{23}$

It may seem that I am exaggerating the role of terror as a signaling device in determining policy implementation, but I am taking my own signals from the experienced Ukrainian old Bolshevik, Mykola Skrypnyk, Ukraine's soft-line Commissar of Education and passionate exponent of Ukrainization. Skrypnyk had long been concerned about the asymmetric deployment of terror against only "nationalists" and not "great power chauvinists": that is, against those who too eagerly implemented the Soviet nationalities policy and not against those who refused to implement it. In June 1923, a TsK Nationalities Conference was held with only two issues on the agenda: practical measures to speed the implementation of Soviet nation-building and the condemnation of the arrested Sultan-Galiev as a nationalist. Skrypnyk enthusiastically supported the first agenda item, but was greatly concerned that the denunciation of Sultan-Galiev would undermine it.

Skrypnyk began his remarks at the conference with an anecdote about how in antiquity, a new building was dedicated by pouring the blood of a sacrificial victim under the cornerstone. Skrypnyk portrayed the persecution of SultanGaliev, whose guilt he openly questioned, as a blood sacrifice poured under the edifice of the new Soviet nationalities policy. However, he complained that there were also many Great Russian chauvinists in Ukraine who falsely persecuted ethnic Ukrainian Communists: "It seems to me that the blood of one of these criminals ought also to be placed under the cornerstone of a correct Party policy, along with the blood of the criminal type, Sultan-Galiev."24 With this appalling metaphor, Skrypnyk candidly pointed to the connection between terror and policy implementation.

The SVU trial naturally alarmed Skrypnyk since it again involved the deployment of terror against only Ukrainian nationalism. ${ }^{25} \mathrm{He}$ responded with a

23. T. Martin, An Affirmative Action Empire, op.cit.: 169-173.

24. Bulat Sultanbekov, ed., Tainy natsional'noi politiki TsK RKP. Stenograficheskii otchet sekretnogo IV soveshchaniia TsK RKP(Moscow, 1992): 62.

25. Another instance of Skrypnyk's concern over the asymmetric use of terror took place in April 1929, when a TsKK inspection accused the Ukrainian government of fighting Russian chauvinism more aggressively than Ukrainian chauvinism. The Ukrainians reacted to this charge with indignation and bewilderment. Skrypnyk was outraged:

"Skrypnyk - I would like to ask in recent time who we have beaten as a Russian chauvinist. What campaigns have we conducted against great power chauvinism. Who have we attacked?

Khvylia - This is our shortcoming.

Liubchenko - Malitskii.

Skrypnyk - And what did we do [to Malitskii]? We gave him a reprimand (vygovor) when as a member of the [Ukrainian] Supreme Court, he demanded, and did so vehemently, that we speak with him only in Russian. After that, how can you say we fight more with Great Russian chauvinism? Did we conduct a campaign [against Malitskii]? No. We had a resolution. And against Shumskyi we conducted a massive battle [...]." (TsDAHOU, f. 1, op. 20, d. 120 (03.04.29), 1.68).

Malitskii was not only a member of the Ukrainian Supreme Court but its President. In January 1928, he had complained bitterly when the book he wrote in Russian was published first in a Ukrainian translation. He was only given a reprimand and allowed to keep his position. Shumskyi was Commissar of Education until 1926, when he protested the slow implementation 
creative strategy designed to defuse the trial's potential to undermine Ukrainization. Unable to stop the SVU trial, Skrypnyk attempted to define it as a necessary attack on the nationalism of Ukrainian bourgeois specialists, undertaken in order to balance the previous attack on the Great Russian chauvinism of the Shakhty specialists, who "were tenacious Russian nationalists. You know the desperate and conscious resistance they offered to [...] Ukrainization and the creation of Ukrainian national culture." 26 In this scenario, both trials primarily targeted nationalism and so politically canceled each other out. However, Skrypnyk later lamented that his interpretation of the Shakhty trial had failed:27

\begin{abstract}
"One unfortunately must confess that this aspect of the Shakhty trial was not emphasized by our press as a separate subject and analyzed from the perspective of nationalities policy theory. And yet this fact is important, very significant. The written declarations, confessions and testimony of the Shakhty wreckers clearly show how hostile they were to the Party's nationalities policy in Ukraine. They showed their Great Russian orientation. In their practical work, they offered fanatical resistance to the Ukrainization of the economic organs, [...] rejecting $[\ldots .$.$] all that even smelled of the Ukrainian language."$
\end{abstract}

This quotation once again shows that Skrypnyk was acutely aware of the policy impact of terror. He was not only desperate that Shakhty be used to balance SVU, but that it also be given a clear policy "line." The Shakhty saboteurs, he insisted, were being punished for the passionate resistance shown to Ukrainization by the all-Union economic organs. As Skrypnyk himself admitted, his attempts failed and Ukrainization suffered as a result. ${ }^{28}$

To sum up, then, any attempt to understand the policy of Ukrainization without considering the actions of both soft-line and hard-line institutions, and without some understanding of how these two policy lines interact, will distort the policy. For instance, an exclusive focus on the actions of the GPU in the SVU trial has led to the argument that Ukrainization was abandoned in 1929. This is an exaggeration. The all-Union economic Commissariats and Trusts did cease Ukrainization, but other institutions continued to work in Ukrainian and Skrypnyk was able to advance Ukrainization in the educational institutions under his authority. On the

of Ukrainization. For this action, he was removed from Ukraine, denounced in a mass public campaign as a nationalist, and finally arrested as the putative head of a counter-revolutionary Ukrainian organization in 1933.

26. M. Skrypnyk, "Kontr-revoliutsiine shkidnytstvo na kul'turnomu fronti," Chervonyi shliakh, 4 (1930): 139; see also, Id., "Spilka Vyzvolennia Ukrainy," Bil'shovyk Ukrainy , 8 (1930): 23 .

27. M. Skrypnyk, "Natsional'ni peretynky," in Statti i promovy. 2: Natsional'ne pytannia. Chastyna druha (Kharkov, 1931): 282-283.

28. On March 20,1930, in the middle of the SVU trial, Skrypnyk pleaded in a letter to Kosior that some balance be achieved within the SVU trial. He asked that a positive witness be allowed to speak about the Ukrainian Academy of Science's potential for positive work on behalf of Ukrainian national culture. He again failed. Volodymyr Prystaiko, Iurii Shapoval, op. cit.: 251 . 
other hand, an exclusive focus on official policy statements and the actions of the soft-line institutions has led to the conclusion that no policy change occurred until 1933. However, as I have indicated, the SVU trial, although it never specifically condemned Ukrainization, effectively ended any hopes for the implementation of comprehensive Ukrainization.

My second example will serve primarily to illustrate the degree to which two Soviet bureaucracies could simultaneously pursue opposing policies without making any reference to each other's actions. ${ }^{29}$ Between 1935 and 1937, a great deal of Soviet attention was devoted to those referred to as "western national minorities": Germans, Poles, Finns, Latvians, Estonians, Lithuanians, Greeks, Bulgarians, and so forth. In 1935, A. I. Khatskevich was appointed Secretary of the Presidium of the Soviet of Nationalities and set out to rejuvenate that moribund institution. Khatskevich was an experienced soft-line specialist, having spent over a decade as Secretary of the Belorussian TsIK. He immediately made the western national minorities one of his top priorities. He ordered a series of inspections of Ukraine, Belorussia and Leningrad oblast', which resulted in highly critical reports. Local officials were accused of neglecting the national rights of Germans, Poles and Finns. After 1934, the number of national soviets, schools and other institutions devoted to those minorities had begun to drop precipitously. The local officials, who responded to these accusations quite awkwardly, were instructed to improve their performance. However, ensuing inspections in Ukraine revealed that the treatment of Germans and Poles continued to deteriorate. Nevertheless, through the fall of 1937, the Soviet of Nationalities continued to make improved treatment of these minorities a high priority. In short, if one looked at the archive of the Soviet of Nationalities alone, one would assume that proper treatment of western national minorities was a major priority of the Soviet nationalities policy from 1935 to 1937, though one would be at a loss to explain why local officials seemed to be pursuing a contradictory policy line.

In order to understand the seemingly brazen behavior of these local officials, one would have to consult the records of the two key hard-line institutions: the NKVD and the Politbiuro. In late 1934, the Politbiuro ordered the NKVD to begin deporting Germans and Poles from the border regions of Ukraine. These deportations began in the spring of 1935 and continued for just over a year until almost half the Polish and German population had been deported from those regions. Similar deportations of Finns from the Leningrad oblast' border regions took place at the same time. Another Politbiuro decree in November 1934 had authorized the mass arrests of ethnic Germans. Acting on these unambiguous signals, the Ukrainian Politbiuro and Belorussian obkom began to abolish German

29. The following section is based on material from T. Martin, An Affirmative Action Empire, op. cit.: 744-769. 
and Polish institutions throughout those two republics. The Leningrad obkom did the same with its Finnish institutions. ${ }^{30}$

What is striking about this example is that, despite the attention devoted to the western national minorities by the Soviet of Nationalities, its bureaucratic records make absolutely no mention of these deportations. The closest I came to finding a reference was a highly euphemistic formulation produced by a Kiev official who, when asked to explain why Polish and German national soviets were being abolished, replied that "the percentage of Polish and German population in the national soviets has changed in the direction of reduction." 31 In other words, the population had been deported. Clearly both the inspectors of the Soviet of Nationalities and the local officials knew the deportations were occurring. However, it was considered politically unacceptable to even refer to this fact in the records of the Soviet of Nationalities. It simply lay outside the competence of that institution. ${ }^{32}$

This example demonstrates, to an even greater extent than the Ukrainization example, the striking degree to which focus on one bureaucracy (or even a set of soft-line or hard-line bureaucracies) can lead to an enormous distortion of the historical record. In the latter example, this was especially true since the two relevant hard-line bureaucratic sources were and remain closed to most researchers. The extensive NKVD documentation on the ethnic deportations were inaccessible to me, since the former KGB archive was and remains closed to researchers without special influence. Likewise, the osobaia papka Politbiuro decisions for late 1934 to 1938 were and remain closed to most researchers. ${ }^{33}$ Fortunately, records related to the financing of the deportations were available in the Sovnarkom archive. ${ }^{34}$ Also, in the Ukrainian Party archive, osobaia papka decisions, including materials to those decisions, were and remain open to researchers, and their documents made reference to most of the key central

30. Only in the fall of 1937 did the all-Union Politbiuro finally order the abolition of all national institutions of the western national minorities and other diaspora nationalities. Deportations continued throughout 1937. With the onset of the mass operations in the summer of 1937, diaspora nationalities also became a target for mass arrest and execution. For these repressive measures, see T. Martin, "The origins of Soviet ethnic cleansing," Journal of Modern History, 70, 4 (Dec. 1998): 813-861.

31. GARF, f. 3316, op. 30, d. 831 (1937), 1. 151.

32. This is also a matter of Soviet rules concerning secrecy of classified information. All mention of ethnic deportations in the period from 1935 to 1938 was placed in the highest secrecy category of osobaia papka (special file). A soft-line institution like the Soviet of Nationalities did not have the right to keep osobaia papka documents.

33. As of May 1999, Politbiuro osobaia papka decisions were open only through early 1934 (RTsKhIDNI, f. 17, op. 162, d. 1-15), though some Russian scholars have access to the later decisions. Likewise, although KGB archives in Russia and Ukraine remain largely closed to foreign researchers, documents about the ethnic deportations have been published by researchers with special influence. The best two collections are Belaia kniga o deportatsii koreiskogo naseleniia Rossii v 30-40-kh godakh. Kniga pervaia (Moscow, 1992). Deportatsii. Zakhidni zemli Ukrainy kintsia 30-kh - pochatku 50-kh rr. Dokumenty, materialy, spohady (L’viv, 1996).

34. GARF, f. 5446. 
decrees. ${ }^{35}$ This example provides only an extreme case of a general rule: soft-line bureaucracies produce a greater volume of records and their records involve a lesser degree of secrecy. For that reason, bias in the direction of the soft-line perspective is undoubtedly the more common error. ${ }^{36}$

The Soviet bureaucratic division of labor could also lead to a second distortion of the historical record: an exaggeration of the extent of bureaucratic conflict in the 1930s. For instance, it would be possible to interpret my second example as an instance of extreme bureaucratic conflict: two bureaucracies simultaneously pursuing diametrically opposed policies. I believe this would be a misinterpretation. If this example were an instance of bureaucratic conflict, the rival bureaucracies ought to have been attacking one another, not ignoring each other's existence and each other's policy actions. In particular, one would have expected the weak Soviet of Nationalities, whose "policy line" was clearly at odds with that of the Politbiuro, to have received a rebuke. This never happened. It never happened, I would argue, because this was not an example of bureaucratic conflict but rather of a bureaucratic division of labor. The job of the Soviet of Nationalities was to pursue a soft-line approach that emphasized servicing the needs of the general population. Likewise, the job of the NKVD was to pursue a hard-line approach that emphasized a militant defense of core Bolshevik principles. This does not mean that bureaucratic conflict did not occur - it clearly did - only that its extent could quite easily be exaggerated if one neglects to consider the bureaucratic division of labor.

It is beyond the scope of this paper to formulate a complete theory as to why the Stalinist bureaucracy was organized in this seemingly peculiar fashion. I will confine myself to a few suggestions. This organizational structure was undoubtedly related to the Soviet regime's simultaneous pursuit of two mutually incompatible goals. On the one hand, it sought mass political support. On the other hand, it endeavored to implement its core Bolshevik values, which involved a dramatic and wrenching social transformation. The former goal involved an appeal to the general population at the expense of the Party faithful, the latter an appeal to the Party faithful which might alienate the general population. One answer to this quandary was an alternation between soft-line (NEP) and hard-line (cultural revolution) policies. ${ }^{37}$

However, another answer was to establish bureaucracies which simultaneously pursued both goals. Hard-line bureaucracies enjoyed greater prestige and power, worked in much greater degree of secrecy, focused their contact primarily on Party members and regime loyalists, and devoted themselves to the defense of core Bolshevik principles. Soft-line bureaucracies were weaker, worked more openly, had contact primarily with the "non-Party masses" and worked to present

35. TsDAHOU, f. 1 , op. 16.

36. As noted earlier, printed sources also lead to this distortion since the soft line is much more fully represented in published sources.

37. On this dimension of hard- and soft-line policies, see Sheila Fitzpatrick, The cultural front (Ithaca, NY, 1992): 91-114. 
the regime in as positive a light as possible. ${ }^{38}$ This bureaucratic division of labor naturally made bureaucratic communication difficult since not all communication could be undertaken in strict secrecy. One could not openly acknowledge this dual structure and its function without undermining the soft-line bureaucracies by exposing their behavior as overtly cynical. The regime, therefore, communicated policy changes through the use of signals, which did not require an overt repudiation of soft-line discourse.$^{39}$ Terror was the most potent of regime signals. Rule by vague signals rather than overt orders served a further purpose. It institutionalized "peregiby" (excesses) by "local officials," peregiby which would in turn be corrected by soft-line institutions. The dialectic of hard-line peregiby and soft-line correction provided the soft-line bureaucracies with an opportunity to fulfill their function of presenting a positive face to the general population, without seriously undermining the pursuit of hard-line Bolshevik policies.

The new archival sources, then, tell a complicated but intriguing story. They certainly provide vast quantities of new details concerning Soviet nationalities policy and many other matters. More interestingly, they illuminate the entire practice of Soviet governance, in particular how the Soviet state communicated with both its agents and its population through often vague and contradictory signals rather than peremptory commands as one might have expected. In turn, this requires the scholar to become an expert in decoding those signals in order to properly interpret the millions of new facts now available for exploration.

September 1998 .

Harvard University

Davis Center for Russian Studies

1737 Cambridge street

Cambridge MA 02138

e-mail:martin11@fas.harvard.edu

38. The foreign policy equivalent of this structure would be the hard-line Komintern and softline Commissariat of Foreign Affairs.

39. There is a parallel here, though not an exact one, to Vaclav Havel's famous parable of the green-grocer who was given a sign "Workers of the world unite!" to put in his store window with the vegetables. Havel points out that the green-grocer does not believe in the content of the slogan nor does the regime expect him to believe in it. Rather, Havel decodes the meaning of the sign as a signal whose functional message to both customers and government officials was instead: "I am afraid and therefore unquestioningly obedient." However, if the green-grocer were required to put up a sign with that hard-line message directly stated, he would understandably consider it an enormous affront to his dignity. Vaclav Havel, "The power of the powerless," (1978) in Living in truth (London, 1986): 41-43. 